\title{
Level of Stress and Coping Mechanisms of Teacher Education Interns of the University of Bohol
}

\author{
IMELDA C. BOLANIO \\ http://orcid.org/0000-0001-8738-9351 \\ icbolanio@universityofbohol.edu.ph \\ JOSEPHINE O. BAAY \\ http://orcid.org/0000-0003-0255-6785 \\ josephinebaay18@gmail.com \\ VIVIAN M. BALIGUAT \\ http://orcid.org/0000-00029539-6669 \\ vivianbaliguat18@gmail.com \\ MARY ANN G. BARBARONA \\ http://orcid.org/0000-0002-3807-3876 \\ barbaronamaeyann18@gmail.com
}

ROSMARIE R. BARINAN

http://orcid.org/0000-0001-9141-6922

rosemariebarinan8@gmail.com

CAITLIN MAY D. LAGRADA

http://orcid.org/0000-0003-0572-3198

Icaitlinmae@gmail.com

KISHA MAE L. RANCES

http://orcid.org/0000-0002-6790-0367

ranceskishamae21@gmail.com 


\section{ABSTRACT}

Stress is a state of mental tension and worry that causes strong feelings. To overcome stress, there is a need to employ some strategies to mitigate threatening and stressful situations. These strategies are known as coping mechanisms. The study aimed to determine the level of stress and the coping mechanisms used by the University of Bohol (UB) - Teachers College student interns. The study utilized the quantitative method to gather data through adapted survey tool. The data gathered were subjected to statistical treatment making use of simple percentage, weighted mean, composite weighted mean, and Pearson-Product Moment Correlation. The respondents were the Teachers College student interns of UB during the second semester of the academic year 2017-2018. The study revealed that the respondents' level of personal-related stress was found to be "Slightly High" with the mean rating of 1.818. The study further revealed that the respondents' level of school-related stress is was discovered to be "Slightly High" with the mean rating of 1.9286 . The level of the coping mechanism which the respondents used is described as "Moderately use" with the mean rating of 2.7054. The study suggests that females are more prone to stress compared to their male counterparts. Based on the results, intervention measures have been proposed to combat the stress experienced.

Keywords: stress, personal-related stress, school-related stress, coping mechanism, teachers, college, education, Bohol, Philippines

\section{INTRODUCTION}

Teaching is a challenging profession and is regarded as a highly stressful job. Indeed, teachers experience extreme stress due to their various tasks and responsibilities. Smith (2012) explained that stress has negative impacts on classroom performance, job satisfaction, and teacher attrition. There are a lot of instances where teachers are placed in a position of highly stressful responsibilities for the actions of young individuals in a school setting. Add on to this is the burden of choosing the right learning activities that would lead to the attainment of the educational goals is also noted. With this premise rise the need to expose future teachers to the realities of their dream profession. 
Internship is a vital part of teacher training program. It is during internship that students are guided in the "dos" of teaching during a fixed period under the supervision of critic teachers (Chireshe \& Chireshe, 2010). In the Philippine context, all teacher education curriculum in all higher education institutions includes practicum teaching as one of the requirements for the degrees of Bachelor of Secondary Education (BSED) and Bachelor of Elementary Education (BEED) (Commission on Higher Education CMO 74, s. 2017).

Part and parcel of being an intern is the actual practice of the duties and obligations of being a teacher as an application of the theories and knowledge learned in the course of study. (Chaplain, 2008 \& Montgomery, MacFarlane, \& Trumpower, 2012). These obligations are coupled with stress. The term stress refers to a condition that causes strong feelings of worry or anxiety that may result in self-doubt, fear and even anger which are all manifested by headaches, body pain, sweating and others. Khodarahimi, Hashim \& Zaharim (2012) cited that stress is experienced much more by college students. There are several factors that cause interns to become stressed - either personal or school-related. To adjust to stress, interns use strategies to cope with these stressors, and these are what are called as coping mechanisms (Carnicer \& Calderon, 2013). Having enough knowledge on how to cope with stress, interns can effectively do things correctly. Congruently, faculty members of the department can help them develop adaptive strategies in managing their stress. (Mapfumo, Chitsiko, \& Chireshe, 2012).

For this, the researchers aimed to determine the level of stress and the coping mechanisms used by the University of Bohol Teachers Education student interns.

Abraham Maslow's Humanistic Theory, particularly on the Hierarchy of Needs explained that the highest need of man is to fulfill his abilities and potentials or self-actualization. This proves that Maslow was much more interested in learning about what makes people happy and what they do to become such. As a Teacher Education intern, it is always his desire to be self-actualized. To achieve this ultimate goal, he has to be able to face squarely the challenges in teaching. He should always be motivated to achieve personal development despite difficulties being encountered. Further developing his self-esteem which would result in his positive relationship with others - students, teachers, and others. 
The Self-Worth theory asserts that a person's ability to attain his goal is directly linked to his perceptions of himself (Covington, 1984). This implies that the feeling of failure must be avoided in whatever circumstances that may come along the way. And since being an intern entails heavy training related to teaching, it can not be denied the possibility of being stressed. But, with motivation and determination on the part of the intern would make all things promising. He would remain steadfast because he sees his worth as a person and as a future teacher.

One of the modern versions of cognitive emotion theory is the Cognitive Appraisal by Lazarus. It emphasizes that assessing the threat tendency of stress and the response of the individual to the stressor are the processes to assess emotions. Here comes the need to use the right coping mechanism in facing the stressful happenings of the internship. Cognitive appraisal is divided into two types: primary appraisal (involves analyzing whether an occurred event is harmful or a challenging one) and secondary appraisal (involves dealing with stressor or the stress it produces). The student should have the focus and a clear mindset to surpass the challenges he may face.

Parallel literature is herein gleaned to amplify the contents of this study. According to the book, Teachers Under Pressure: Stress in the Teaching Profession by Travers and Cooper (1996) that there are factors that impose pressures to the teachers including primary factors like pupil's behavior which has a direct effect on teachers in the classroom. Another is secondary factors or the environmental-based factors which affect the situation where teaching happens.

Parallel to this is the analogy on personality traits and coping processes by Lazarus (1993). In his essay, he made mention that there are people who resist the harmful effects of stress better than others. The following includes constructive thinking, hope, learned resourcefulness, optimism, self-efficacy, and sense of coherence.

Related to Lazarus' analogy is the writings of Lyon (2012). She emphasizes that the effects of stress are manifested through cigarette smoking, crying, too much eating, shaking, and drinking alcohol.

A study conducted by Montgomery et al., (2012) stated that the level of stress experienced by the student interns in terms of school-related issues was stressful specifically in teaching practice, teaching evaluation, and academic concerns. While the study of Saïas, Roscoät, Véron, \& Guignard, Legleye \& Beck (2014) reported that women and students who experience 
problems with money were known to have serious levels of psychological distress. The study conducted by Georgieva, Georgieva, Zahariev, \& Pesheva (2014) declared that stressors related to academics were the major sources of stress $(59.7 \%)$ for both male and female medical students.

Stress can influence the student's academic performances. Various mechanisms were used to cope with the stress. Based on the study of Bam, Oppong, \& Ibitoye (2014), the most used coping strategies were spiritual guidance like praying to God when facing difficulties, building a cordial relationship with others, and getting moral support from the family.

Another study of Deasy, Coughlan, Pironom, Jourdan, \& McNamara (2014) reported the avoidance of dealing with the stressor, so with emotionfocused were used most often as a coping technique by the female students ranging at the age of 26 below than in males. While positive reappraisal was used by the students ranging the age of 26 and above.

Meanwhile, the study of Mundia (2010) found out that in terms of applying the coping strategies, the gender and program of study were known to have no significant differences. Meanwhile, there was no significant correlation between gender, age, and program of study. This was contrasted with the study of Bam et al. (2014) that indicates, the older the student, the lower the level of stress they experienced.

Based on the study of Verdonk, Räntzsch, De Vries, \& Houkes (2014), those who are reported to have higher stress, and cope up with the expectations by studying hard are female students. It coincides with the study of Bamuhair, Farhan, Althubaiti, Agha, Rahman, \& Ibrahim (2015) which reported that female students encountered a higher level of stress, more sources of stress, and used more coping strategies than males. The study of Georgieva et al. (2014) also reported that those who experienced more stress are female medical students.

Republic Act 7836 also known as the Philippine Teachers Professionalization Act of 1994 was enacted to strengthen the supervision and regulation of the teaching profession in the Philippines. The said law recognizes the vital role of teachers in nation-building and development through a responsible and literate citizenry, and thus, it shall be the government's role to ensure and promote quality education by the proper regulation and supervision of the licensure examination and professionalization of the practice of the teaching profession. Government agencies such as the Professional Regulation Commission and the Commission on Higher Education (CHED) are empowered to look into the conditions affecting the teaching profession whenever necessary, adopt proper measures for the 
continued enhancement of the high professional and ethical standards of the profession.

Furthermore, CHED Memorandum No.23 Series of 2009 states that every educational institution should provide tertiary students enrolled in Higher Education Institutions in the Philippines the opportunity to acquire practical knowledge, skills, and desirable attitudes and values in reputable establishments or industries in the Philippines. Thus, as tertiary students, student interns must be exposed to activities which give them the opportunity to acquire practical skills and experiences.

The primary thrust of the study was to determine the level of stress experienced, and the coping mechanisms used among the Teacher Education student interns of University of Bohol, for the second semester of academic year 2017 - 2018.

\section{RESEARCH METHODOLOGY}

The researchers used descriptive survey for the level of stress and coping mechanisms used by the UB-TC student interns for the second semester of the academic year 2017 -2018. A standardized questionnaire was used in conducting the study. It was essentially a method of quantitative description of the group's general characteristics.

The University of Bohol main campus was the locale of the study. This school is bounded by the following streets: on the North, Dr. Cecilio Putong Street; on the South, Rafael Palma Street; on the East, Carlos P. Garcia Avenue and on the West, Remolador Street. The respondents were all the 98 student interns of Teachers College of the University of Bohol for the second semester of academic year 2017-2018.

The main tool was used in determining the level of stress and coping mechanisms of the UB - Teacher Education interns for the second semester of the academic year 2017-2018. There were 47 items in all. The instrument obtained items on matters pertaining to the level of stress experienced by the student teachers, and the coping mechanisms used.

The standardized questionnaire by Barreca and Hepler (2000and Ying Ming Lin and Farn Shing Chen are used in a Likert - type scale. The following legends are used for the level of stress: $\mathrm{VH}$ - Very High, $\mathrm{MH}$ - Moderately High, $\mathrm{SH}-$ Slightly High, and $\mathrm{H}-\mathrm{High}$. And the legends used for coping mechanisms are: AU - Always Used, MU - Moderately Used, SU - Slightly Used, and NU - Never Used.

The questionnaire was submitted to the research adviser and to the Vice President of Academics for the selection of the items to be used. After securing 
a final list of the UB Teacher Education interns from the University Registrar's office, permission was sought and secured from the Dean of the Teachers College Department and the Vice-President of the Academics. The study was then submitted to the Reseach Ethics Committee and was issued a certificate to proceed with data gathering. Letters of consent were signed by the respondents and copies of the questionnaire were distributed to them. The respondents were given the assurance to the utmost confidentiality of the data.

The survey was conducted during the off-campus internship of the respondents. Then, retrieval activity was done, and the data was tabulated, analyzed and interpreted. The gathered data were arranged in tables for easier numerical comprehension and statistically treated for further analysis and interpretation. The findings served as bases for the conclusions and recommendations.

\section{RESULTS AND DISCUSSIONS}

The level of stress experienced by the student interns in terms of personalrelated stress was labeled as "Slightly High" with the mean rating of 1.818. Among the 98 respondents, 48 respondents had scores above the mean, and 50 respondents had scores below the mean. The item on $A$ family memberffriend has been sick or died ranked the highest with a mean of 2.3877. This result concurs with the study by Bamuhair et al. (2014) wherein hearing bad news was found to be the top stressor of undergraduate medical students in Saudi Arabia.

The level of stress experienced by the interns in terms of school-related stress was labeled as "Slightly High" with the mean rating of 1.9286. Among the 98 respondents, 61 respondents had scores above the mean, and 37 respondents had scores below the mean. The result showed that Trying to complete reports and paperwork on time causes me a lot of stress is the number one source of stress among interns which concurs with the study of Georgieva et al. (2014) wherein stressors related to academics were the major sources of stress $(59.7 \%)$ for both male and female medical students. The findings validate the claim of Montgomery et al., (2012) that the level of stress experienced by the student interns in terms of school-related issues was stressful specifically in teaching practice, teaching evaluation, and academic concerns.

The results also showed that the female interns were at risk of higher stress in school-related activities which supports the findings of Verdonk et al. (2014) which showed those who were reported to have higher stress and cope up with the expectations by studying hard were female students. 
The level of the coping mechanism the student interns used was labeled as "Moderately use" with the mean rating of 2.7054. Among the 98 respondents, 52 respondents had scores above the mean, and 46 respondents had scores below the mean. The result showed that the number one coping mechanism used by the student interns is I look for religious hope or comfort for my soul which in line with the study of Bam et al. (2014) that the most used coping strategies were spiritual guidance such as praying to God when facing difficulties, building cordial relationship with others, and getting moral support from the family.

\section{CONCLUSION}

Student interns were having difficulties in time management when it comes to completion of reports and paperwork. Despite these difficulties, they can continue achieving their goals as the Humanistic Theory: Hierarchy of Needs stated that with motivation, an individual could achieve personal development and the desire to fulfill one's abilities despite failures and difficulties he has.

Also, student interns preferred to communicate with God rather than drinking alcohol, decreasing their standard, or using their mistakes to surrender as their coping techniques which are in line with the theory of Selfworth which stated that the feeling of failure must be avoided though hard times may come. This emphasizes having the feeling of being able and positive to achieve something. Thus, motivation to achieve the goal is the key to success.

\section{RECOMMENDATIONS}

The following recommendations are suggested to help the interns cope with the stress being experienced:

1. The faculty must strengthen the guidance counseling program, or there should be a separate guidance counselor for the student interns alone.

2. Financial management seminars should be embedded as an extra activity to capacitate students before taking their internship.

3. The faculty must integrate fun learning activities during their weekly feedbacking sessions. 


\section{REFERENCES CITED}

Bam, V., Oppong, G., \& Ibitoye, M. (2014). Stress and Coping Mechanisms of Nursing Students During Clinical Practice in Ghana. Journal of Science and Technology, Vol. 34, No. 2, 50-59. Retrieved from https:// goo.gl/NXJVrX, (accessed last 15 February 2018).

Bamuhair, S. S., Al Farhan, A. I., Althubaiti, A., Agha, S., Rahman, S., \& Ibrahim, N. O. (2015). Sources of Stress and Coping Strategies among Undergraduate Medical Students Enrolled in a Problem-Based Learning Curriculum. Journal of Biomedical Education. Retrieved from https:// goo.gl/XQ2tbM, (accessed last 15 February 2018).

Carnicer, J. G., \& Calderon, C. (2013). Coping strategies and psychological well-being among teacher education students. European Journal of Psychology of Education,28(4), 1127-1140. Retrieved from https:// goo. gl/vG1FQL, (accessed last 31 January 2018).

Chaplain RP (2008) Stress and psychological distress among trainee secondary teachers in England. Educ Psychol: Int J Exp Educ Psychol 28:195-209. Retrieved from https://goo.gl/fyxKkd, (accessed last 15 February 2018).

Chireshe, R., \& Chireshe, E. (2010). Student teachers' perceptions towards teaching practice assessment. South African Journal of Higher Education, 24(4), 511-524. Retrieved from https://goo.gl/bsSDmC, (accessed last 18 January 2018).

Covington, M. V. (1984). The self-worth theory of achievement motivation: Findings and implications. The Elementary School Journal, 85(1), 5-20. Retrieved from https://goo.gl/4chPVp, (accessed last 16 February 2018).

Deasy, C., Coughlan, B., Pironom, J., Jourdan, D., \& McNamara, P. M. (2014). Psychological Distress and Coping amongst Higher Education Students: A Mixed Method Enquiry. Plos One. Retrieved from https:// goo.gl/urGh9t, (accessed last 25 February 2018). 
Georgieva, E. K., Georgieva, L. M., Zahariev, V. I., \& Pesheva, P. A. (2014). Stress and stress factors among medical students in Bulgaria. Albanian Medical Journal, 2. Retrieved from https://goo.gl/nboFVS, (accessed last 15 February 2018).

Khodarahimi, S., Hashim, I., \& Zaharim, N. M. (2012). Perceived Stress, Positive-Negative Emotions, Personal Values and Perceived Social Support in Malaysian Undergraduate Students. International Journal of Psychology and Behavioral Sciences, 2, 1-8. Retrieved from https:// goo.gl/XXYxY4, (accessed last 15 February 2018).

Lazarus R.S. (1993). From Psychological Stress to Emotions: A History of Changing Outlooks. Annual Review of Psychology. Retrieved from https://goo.gl/nty2Ub, (accessed last 15 February 2018).

Lyon, B. L. (2012). Handbook of Stress, Coping, and Health: Implications for Nursing Research. SAGE Publications. Retrieved from https://goo. gl/WcALCJ, (accessed last 21 February 2018).

Mapfumo, J. S., Chitsiko, N., \& Chireshe, R. (2012). Teaching Practice generated stressors and coping mechanisms among student teachers in Zimbabwe. South African Journal of Education, 32, 155-166. Retrieved from https://goo.gl/9TfnYx, (accessed last 18 January 2018).

Montgomery, C., MacFarlane, L., \& Trumpower, D. (2012). Student Teacher Stress And Physical Exercice. San Diego: American Society of Business and Behavioral Sciences,19(1:974-992). Retrieved from https://goo.gl/ BNzuEx (accessed last 29 January 2018).

Mundia, (2010). Brunei Trainee Teachers' Coping Strategies for Stressful Situations. International Journal of Psychological Studies, Vol. 2, No. 1 , 79-88. Retrieved from https://goo.gl/yhuZcL, (accessed last 18 January 2018).

Saïas, T., Roscoät, Véron, L., Guignard, R., Richard, J., Legleye, S., Beck, F. (2014). Psychological distress in French college students: Demographic, economic and social stressors. Results from the 2010 National Health Barometer. BMC Public Health 14:256. Retrieved from 
https://goo.gl/D45wrm, (accessed last 19 January 2018).

Schunk, D. H. (2012). Learning Theories: An Educational Perspective (6th ed.). Boylston Street, Boston, MA, 02116: Pearson Education.

Smith, Kasee L., "Coping Mechanisms and Level of Occupational Stress Among Agriculture Teachers and Other Teaching Populations" (2012). All Graduate Theses and Dissertations. 1391. Retrieved from https://goo.gl/ZqiT7n, (accessed last 20 January 2018).

Travers, C. J., \& Cooper, C. L. (1996). Teachers Under Pressure: Stress in the Teaching Profession. Abingdon,Oxon: Routledge. Retrieved from https://goo.gl/Qf5tKo, (accessed last 15 February 2018).

Verdonk, P., Räntzsch, V., De Vries, R., \& Houkes, I. (2014). Show what you know and deal with stress yourself: A qualitative interview study of medical interns' perceptions of stress and gender. BMC Medical Education, 14:96. Retrieved from https://goo.gl/1wbf3W, (accessed last 22 January 2018). 